\title{
3. Policy, papers and pages: Improving media engagement in the Pacific
}

\section{COMMINIAARY}

Merits and drawbacks exist in all forms of media across the world, so Pacific Islanders would do well to deeply consider the kind of journalism they want to cultivate in their region. While exposition of media freedom issues is important, there are other ways to progress the media freedom cause aside from raising awareness and discussing the issue explicitly. Media outlets and professionals should stay mindful that they have a role to play in shaping and informing policy discussions and need to recognise that the internet and social media are changing the game - and both government and traditional media can engage more with the online world. The author argues that better connectivity and engagement between media, government and international organisations can help improve quality journalism.

Keywords: culture, democracy, media freedom, public agenda, social media

\section{TOBY LEY}

Pacific Institute of Public Policy, Port Vila

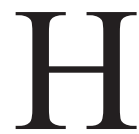

AVING been detained for questioning 16 times between December 2006 and July 2007, the former chief executive of Fiji Broadcasting ble challenges he faced, Herman wonders whether things could have worked out differently:

I think we failed. And it's easy for me to talk because I'm out of the country, but I think we could have... we didn't try to engage them, we should have engaged them. What we did was fight them and we'd lose anyway, but what didn't happen and what hasn't happened in my view, is that the media really hasn't engaged the military to the extent of saying, 'Okay these are the options, have we tried this or can we 
just try that?' I did it in 1987 we did it in 2000. I was Parliamentary reporter in 1987, I was acting chief executive in 2000 when they had the Speight coup and I slept in the office for 56 days. But we managed to get them to see things...

When the military took over and they planted people in our newsrooms in $2006 \ldots$ we rang the military and said, 'We need to talk'... We sat with the military top brass, and we said, 'Take your military out and let's engage' and they agreed. Immediately they withdrew their military from the newsrooms, our people were able to function. But I don't think we did enough of that... I think moving forward, the media really needs to look at, did it cause a lot of the aggression that led up to 2006? And I'm saying yes it did, the way we reported, and I'm to blame as well, it was top news, it was hot news, the Prime Minister fighting the military, it was awesome news.

But we never stood back and analysed it and said, 'Okay, what is the impact?' I don't think we spent enough time thinking about the impact of the stories and the programmes we have. Having said that I don't agree with any form of censorship. (Herman, F., interview with the author, 8 August 2012)

Is the idea of a free and open press antithetical to Pacific ways of life? No, freedom of expression is an inherent part of it, with people holding open discussions under the banyan tree, for example, for thousands of years. So, what are the best ways for us, here in the Pacific to reclaim and enhance this freedom?

\section{Media freedom and the people}

No matter where a journalist resides or whom they work for, they face pressures to publish certain stories in certain ways. Indeed all people in the employ of others are required to accept some degree of personal compromise. Regardless, stories can still play a role in focusing public attention on particular topics and effectively 'set' the public agenda by consistently and prominently featuring issues in their news coverage (Soroka, Lawlor, Farnsworth \& Young, 2013). So, while it may be hard to name a specific corrupt politician for fear of censorship or retribution, it might be possible, without a journalist being overly explicit, to highlight departmental funding received in the last budget, the promises made prior to the last election, the lack of progress made on certain projects and let the people themselves, given the key pieces of information, come to their own conclusions. 
Sometimes too, it seems the media have a yearning to focus on conflict, scandal and gloom. In the West, there is an overt tendency to sensationalise events and fan the flames of fiery issues. Numerous studies fault reporters for focusing on trivial issues, for being too closely tied to official sources, for not providing sufficient context to understand contentious policy options, for their biases and for lacking technical proficiency in matters they write about (Soroka et al., 2013). These are issues faced by all media, free or not. These challenges should be kept in mind as we explore the issue of media freedom. This can lead one to wonder where the ideal media models exist. Is it in the USA, the home of Fox News? Is it Australia where media ownership is concentrated in the hands of a few? Media freedom is a worthwhile cause but if we are to jump onto a media freedom bandwagon, it is worth considering where this ride will end. Do Pacific Island nations want to emulate a Western style of media or do we want to develop something of our own?

Western journalism, I personally have a problem with because all they're doing is looking for conflict and wherever there is a conflict that's where they parachute their journalists... and I just think that is so shallow and restrictive. We need to move on and really tell the stories of our people. (Moala, K.,interview with the author, 12 July 2012)

As we strive toward freedom, we should take a moment to consider what kind of media we want to exist in our region down the track. While the traditional, cultural and demographic aspects of our societies, along with fears of suffering retribution can result in censorship, self-imposed or otherwise, Pacific journalists can still present important issues in ways that feel natural to them and will appeal to their readers. It is possible to display respect while also informing the public.

You don't have to be gung-ho. You don't have to be a star; you get no points for it but it's how you engage with them... There are other ways of doing it, other ways to skin the cat. I think we give up too quickly. It's not that we are limited in our intellect or anything, but I think we are so steadfast in, 'This is the only way to do it' but we have to fight for freedom, we can't give in. (Herman, F., interview with the author, 8 August 2012)

The media are widely acknowledged as playing a role in policymaking, primarily through 'agenda-setting' and 'issue framing'. By writing certain 
stories, the media can help set the agenda for politicians, policymakers and other actors. In their framing of issues, the media can influence the way a subject is discussed, in turn influencing public opinion. The media are able to communicate not only to the people from the government but to the government from the people too. Politicians rely on media cues to help inform their decisions and actions, especially on subjects likely to result in electoral punishment. While it can be more challenging to communicate completely openly in the Pacific, it is possible, especially when done in a Pacific way.

No two democracies are the same and it would be impossible to find consensus on which nation's democracy is best. While it can't be denied that a free media can help improve accountability, lift the standard of public servants and improve governance in other ways, it is worthwhile to recognise that each democracy has its flaws and we should be careful in assuming we know how best to 'fix' a sovereign nation's democratic system and/or media. After all, it is not only governments that have the potential to limit media freedom; the church, lobbyists, media owners, old prejudices, and personal biases limit freedom too. Journalists, like politicians, are human and are not incorruptible.

I've been to many seminars at conferences, where people get up have all this big talk... and say media serves democracy and we do things that serve democracy and sometimes I wonder, what about the people? I thought we were meant to serve the people. Where are the people? Sometimes in a democracy the people are caught in a network down below and the democracy is just for a few'. (Moala, K., interview with the author, 12 July 2012)

A free media are essentially good for democracy but it is worth considering how much the wider population of the Pacific knows about and understands the importance of media freedom. Do people in remote villages, living subsistence lifestyles really think about media freedom and the intricacies of politics in a distant capital city or do they focus more on the lack of decent roads, hospitals, schools and the regularity of ships to take their copra? If they hear a radio report about a media freedom conference in the capital, will they be encouraged and motivated to act? Or would they react more to a story highlighting their plight in relation to the state of their roads, and the funding promised for it at the last election? 
Critical policy discussion is limited by lack of knowledge on the reporter's part and a belief that there is little interest in the issues from the public... To overcome it, try it. And try and do it in a way that is engaging, which breaks the issue down and will relate to those affected. (Cooney, C., correspondence with the author, 18 August 2012)

\section{Considering a strategic struggle}

Radio Australia journalist Sean Dorney argues that in a climate where some Pacific governments appear to have a belief that the media is something to, 'be controlled and do what we want it do', the media's attention on itself is not obsessive and that 'the media needs to keep on its toes' (Dorney, S. correspondence with the author, 13 August 2012). At the same time though, Dorney recognises that the issue of media freedom probably is not at the front of a lot of people's minds.

If you look at the survey (Hayward-Jones, 2011) done in Fiji where 66 percent of people supported Bainimarama, yet there is near universal support and great value placed on media freedom too. Underneath it all, people want to know what's going on! They don't want to be fed propaganda. (Dorney, S. correspondence with the author, 13 August 2012)

There is no denying that a free and open media is a worthwhile goal and that a free media can strengthen democracies, but it may be prudent to reflect on how much time, resources and attention we should spend on self-reflection and pity for the industry. Keeping an issue topical is important but we should be wary of displacing other stories, which may be indirect but equally effective in garnering stronger democracies. Perhaps media freedom can be just as well achieved by making the best of a difficult situation and working within the context in which we find ourselves? Do we need a rethink around the idea of public broadcasters, given the questions of how effective they are? With state-owned broadcasters often ending up as little more than government mouthpieces, perhaps it is time to recognise that even if State broadcasters are unlikely to give an independent view and unlikely to speak negatively it would still be worth encouraging those journalists to find some kind of middle ground. It is possible for journalists to work for the State but still have a positive impact by improving on their own brand of development journalism, hopefully with commercial and/or social media increasingly playing some sort of watchdog role. 
The genius of journalism today is that there are situations, conflict situations where you can manoeuvre around it... If government don't want their stories, tell the other stories! There are a lot of other stories... society is so one-dimensional when we only think that politics is the one main area. (Moala, K., interview with the author, 12 July 2012)

There is an abundance of expertly-written articles to be found centring on issues of media freedom in the South Pacific and entire organisations exist to promote the issue but how many of these articles resonate with the "man on the street'? How many of the stories reach him? Journalists, academics and the media at large could consider writing more articles that will engage the community at large, not just their colleagues. Perhaps a freer media can best be achieved not only by writing about the topic and asking for it directly from government, but by giving the community itself a thirst to read and learn more.

Just as scholars in Eastern Europe have accused donor-sponsored anticorruption campaigns of encouraging populism and discrediting leaders, displacing debate about policies, and contributing to popular disillusionment with democracy (Larmour, 2012, p141-161), media freedom campaigners should be wary of having a similar effect. An inflated rhetoric of media freedom could undermine the very democracies that media freedom advocates hope to bolster and give those countries' media themselves a lower public standing. Focusing incessantly on conflict scenarios and a lack of freedom, the media may inadvertently give an excuse to leaders to be more authoritarian and create a self-fulfilling prophecy of greater oppression.

Publicly what's going out is that we are all fighting among ourselves. Everyone is on an ego trip. Seriously. We're all fighting among ourselves to see who is president of this, who is secretary of that, which country will host. And that for me is irrelevant. Already, there is that 'us and them' kind of thing there and we need to move past that. (Herman, F., interview with the author, 8 August 2012)

\section{Technology and the media}

You find with social media people, you hardly find them talking about media freedom, they've got it, you know. (Moala, K., interview with the author, 12 July 2012) 
Technological advancements are making it more possible than ever to employ alternative media in order to communicate more freely. ${ }^{1}$ The opportunities presented by social media applications such as Facebook, Twitter and the proliferation of blogs are obvious examples. Even if newspapers are muzzled, it is possible to make blogs that are not. The internet has not yet penetrated the wider population of the South Pacific to the extent that mobile phones have, but with submarine cables expected to make their way to Tonga and Vanuatu in the near future, the increasing affordability of smart phones and trends of urbanisation (Urban Hymns, 2011), it is only a matter of time before the majority are connected (Graphs 1 and 2). While the percentage of internet users overall and the number of Facebook users is low, the broader impacts of social media on democracy and development are significant (Cave 2012, Logan 2012). The argument that the internet and social media are not relevant in the Pacific is losing validity and news media outlets need to adjust if they want to remain relevant and influence Pacific populations.

I think it's still growing, I don't think it's as big as it can be just yet, although having said that, we're dealing with the government and

\section{Graph 1: Mobile-cellular subscriptions per 100 inhabitants}

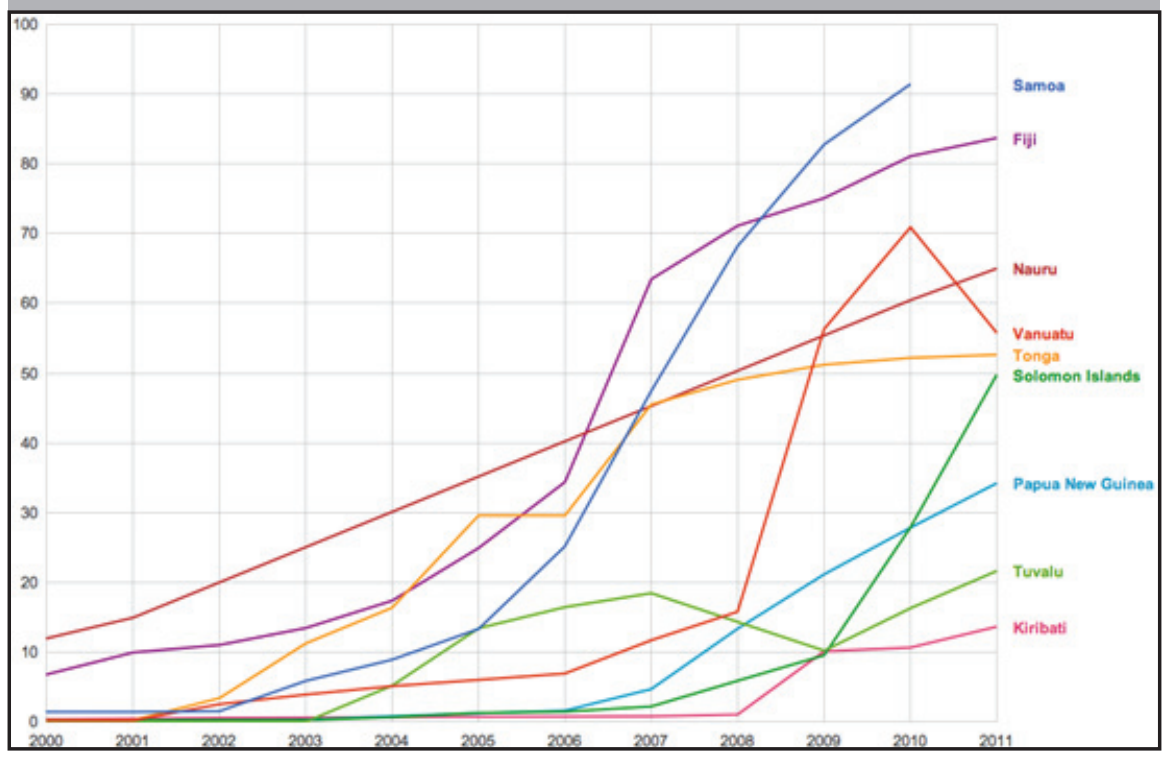

Source : International Telecommunication Union (retrieved on April 15, 2013) www.itu.int/ITU-D/ict/statistics/explorer/index.html

64 PACIFIC JOURNALISM REVIEW 19 (1) 2013 
dealing with the private sector and people in authority. Most of the people online are people that are working and in jobs, sort of like the middle class and they're able to influence the leaders - in government and business - and are also in the cities and towns as well. So, although it may not represent the entire country in terms of reach, it is discussion and interaction that is taking place on some level and with influential people. (Narakobi, E., interview with the author, 10 August 2012)

Pacific Islands' media outlets can do more to tap into web-based applications like Facebook to engage their readership and spark important debates. Even a restricted media can provide information that can act as a catalyst for a public hunger for 'real' news. The pursuit of complete media freedom is an uphill battle, made tougher by a public that doesn't always understand what that really entails and what level of freedom they currently have. As social media penetrate populations and the public comes to hunger for more news and more truthful reporting, journalists and editors will become further enabled, with wider public support, to print stories that may not be possible at present. It is not uncommon for people posting on Facebook to call on

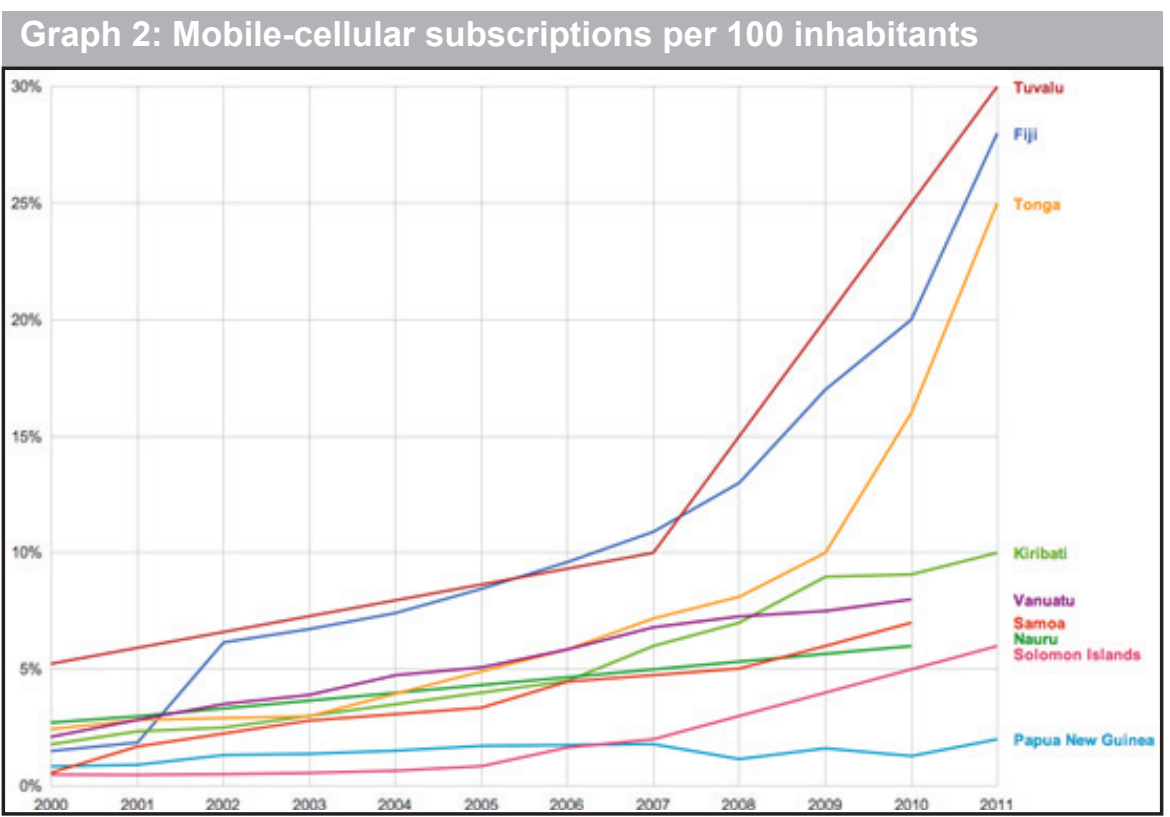

Source : International Telecommunication Union (retrieved on April 15, 2013) www.itu.int/ITU-D/ict/statistics/explorer/index.html 
journalists to verify facts and check on the validity of rumours. This would suggest that journalists are respected to some extent as professionals with investigative skills. Perhaps journalists could do more to capitalise on these opportunities to ensure they stay relevant in a new era of information and communication technology.

Young people, they're not watching television, they don't get information from newspapers any more, it is from social media and I think many of us professional journalists and information people have not woken up. We talk about it at conferences but we haven't woken up to the fact that this is where the world is moving! The flame of journalism has been snatched up from our hands and made common. There is power now among the consumers, and the consumers are producing the information, the delivery, and it is fast! And in many ways it's getting more professional. (Moala, K., interview with the author, 12 July 2012)

A poignant example of where social media appear to be fomenting change is in PNG. As technology becomes cheaper and more accessible, the people themselves, not journalists, have the potential to drive change. So where does this leave traditional media? Cooney notes that in places like PNG, 'social media has given an outlet for those with a view not always being covered in the mainstream media' but at the same time, he laments a lack of 'informed policy debate on social media' (correspondence with the author, 18 August 2012). An objective article explaining key points placed on a Facebook page for example, can further inform people who are already engaged and motivated to discuss issues. Again, the article itself does not need to be controversial or inflammatory to effectively stimulate debate and help the people come to their own conclusions. Social media hold traditional media to account. If the one-nightly news bulletin tells the public everything is okay as thousands of your online countrymen scream otherwise, which media would you believe? There is also a role for traditional media to engage with social media more actively. Sean Dorney, who covered the elections in PNG, interacted with the Tarvurvur Garamut blog, noting that it was,

...miles ahead of the Electoral Commission in terms of keeping me up to date. Also interesting were all the comments coming to the blog from outside and the lively exchanges. You never would have seen anything like that five years ago. (Dorney, S., correspondence with the author, 13 August 2012) 
The ability of ordinary people to create and sustain a new narrative is vital in the development of democracies. The internet allows citizens, ' $\ldots$ to change their relationship with the public sphere. They no longer need to be consumers and passive spectators. They can become creators and primary subjects. It is in this sense that the internet democratises' (Benkler, cited in Montgomery, 2008, p. 26).

I think the media have made a couple of attempts with trying to speak about issues and trying to create different formats like TV programmes and so on but they haven't been doing it effectively... They haven't really taken into account the social media where there are a handful of people bringing up issues and discussing things in a more comprehensive manner which could get more involved in the whole traditional media conversations. (Narakobi, E., interview with the author, 10 August 2012)

Social media is an area that can be better engaged with not only by journalists, but by governments, civil society and others too. Social and traditional forms of media can improve their interaction and draw on each other more often. But these relationships need to be cultivated with care. Narakobi mentions an issue where,
A Post-Courier journalist cut and pasted a blogger's text for a front page article without any acknowledgement. This is not the first time and this creates a divide of 'us and them'. Blatant plagiarism is not ac- ceptable. The only media that has been effectively using content from social media here has been Radio Australia. (Narokobi, E., interview with the author, 10 August 2012)

Interestingly, Fiji is a place where the government has fought online fire with online fire. Unable to stop anti-regime bloggers, a number of pro-regime blogs began to appear, countering accusations leveled at the regime (Foster, 2007; Net Benefits, 2012; Walsh, 2010). Despite the incredibly tough time faced by journalists in Fiji, new opportunities to engage appear to be becoming available, with Bainimarama and the Constitution Commission headed by veteran Kenyan lawyer, Professor Yash Ghai, calling for public input and claiming that consultation sessions would have an 'open, free, fair and fearless atmosphere when making submissions' (Loanakadavu, 2012). Despite the ultimate rejection of the Ghai draft, some elements of the document 


\begin{tabular}{|c|c|c|c|c|}
\hline Country & $\begin{array}{c}\text { Total Facebook } \\
\text { users }\end{array}$ & $\begin{array}{c}\text { Facebook } \\
\text { penetration of } \\
\text { total population }\end{array}$ & $\begin{array}{c}\text { Facebook } \\
\text { penetration of } \\
\text { online population }\end{array}$ & $\begin{array}{c}\text { Name of, } \\
\text { and number } \\
\text { of members in } \\
\text { country-focused } \\
\text { Facebook group }\end{array}$ \\
\hline Fiji & 203,780 & $23.26 \%$ & $159.77 \%$ & $\begin{array}{c}\text { Fiji Politics Forum } \\
2,037\end{array}$ \\
\hline Kiribati & 3720 & $4.02 \%$ & $41.52 \%$ & - \\
\hline Nauru & 460 & $4.57 \%$ & N/A & $\begin{array}{c}\text { Nauru Politics } \\
1,484\end{array}$ \\
\hline $\begin{array}{l}\text { Papua New } \\
\text { Guinea }\end{array}$ & 132,860 & $1.88 \%$ & $18.45 \%$ & $\begin{array}{c}\text { Sharp Talk } \\
10,388\end{array}$ \\
\hline Samoa & 18,920 & $9.85 \%$ & $147.64 \%$ & $\begin{array}{c}\text { Palamene o } \\
\text { Samoa - } 2,771\end{array}$ \\
\hline Solomon Islands & 18,200 & $3.25 \%$ & $67.64 \%$ & $\begin{array}{l}\text { Forum Solomon } \\
\text { Islands - } 6,806\end{array}$ \\
\hline Tonga & 11,400 & $9.30 \%$ & $91.30 \%$ & - \\
\hline Tuvalu & 2000 & $19.10 \%$ & $81.43 \%$ & - \\
\hline Vanuatu & 8,840 & $3.99 \%$ & $46.11 \%$ & $\begin{array}{l}\text { Yumi Toktok } \\
\text { Stret - } 10,098\end{array}$ \\
\hline
\end{tabular}

Sources: Compiled using data from: www.socialbakers.com/facebook-statistics/; www.facebook.com

remain in the regime's updated version and the Fijian people and the media have been afforded some (albeit constrained) opportunities to put forward their opinions. A strategic, measured approach by local journalists during such consultations and future ones could prove fruitful and these occasions for constructive engagement should not be wasted.

\section{Face-to-Face}

What is not there is a space where people can discuss things. It's absent. What is the media doing to create that space? The media claim they're doing it but in reality if you were to do a content analysis of what they're doing, it's what I would call 'developmental journalism'. It's to do with supporting, I suppose, the government's development policies... (Herman, F., interview with the author, 8 August 2012)

Apart from social media, there are other ways to let the population access information and express themselves more freely. For example, The Pacific 
Institute of Public Policy's (PiPP) MP Face to Face programme in Vanuatu brings politicians face to face with their constituents in an open-forum style question-and-answer setting. An integral component of the events is that they are usually broadcast in a live and uncensored format across the country through Radio Vanuatu. PiPP doesn't push a particular agenda; it provides an opportunity for discussion to take place and allows the public to ask the questions most meaningful to them. All the media need to do is turn up and record it. The radio network or the TV channel can't be blamed if an angry citizen accuses a politician of misappropriating funds. This live, open-forum style provides an excellent avenue for the public to be heard and for the media to cover something raw and uncensored. It also gives politicians a greater sense of accountability. While the costs associated with getting journalists to outer islands and the equipment required can be prohibitive to many Pacific news agencies, development partners can probably be drawn on to assist. Lofty goals like improving governance and capacity tie in well here. Programmes like MP Face to Face also provide opportunities to find out what issues the electorate care about, which inform governments and provides journalists with valuable cues they can draw on and help guide them in deciding where to focus their efforts.

\section{Improving connectivity}

Even in Pacific countries with relatively high levels of media freedom, there are weaknesses in reporting. We need to be wary of conflating issues of media freedom with other causes of poor media production. There is room for journalists, development partners and governments to work together better. A couple of fundamental challenges facing traditional media in the region include low wages and a situation where many of the best reporters are 'sucked out' by international organisations or governments themselves. These factors make it especially difficult for overworked journalists.

The media don't have a lot of money and they don't have the time to devote to great investigative journalism. It's really a matter of getting that paper out each day. There is not a lot of time to sit around and discuss issues so deeply, and that is the same all over the region. It's in the nature of media itself. There just aren't that many people there to dig and dig and dig and come up with the gems. (Dorney, S., correspondence with the author, 13 August 2012) 
These days, everybody is in the information game, and for the media to operate better, Pacific governments themselves need to improve their communication skills too. At present, journalists are forced to spend too long digging for basic information that governments should be able to provide as a matter of course. Easier access to information would let journalists get the basic information quickly and then have more time to spend adding value, using their journalistic skills. Here too lies a potential role for international organisations - information conduits for journalists. The wealth of statistical data and willingness most organisations have to co-operate with media are resources worth tapping into. Most organisations are only too happy to have the fruits of their research shared more widely in the hope that policy reform can gain public traction. There is a symbiotic relationship between media and policy specialists here worth nurturing.

If I were working in an NGO I'd offer regular columns directly to newspapers. It probably happens already. The media here in the Pacific are often so desperate for content, it's wide open to people wanting to put their point of view forward and there's a good avenue there for them. (Dorney, S., correspondence with the author, 13 August 2012).

Of course, there are also potential pitfalls that need to be considered. It could be tempting for newspapers to just copy and paste a report that is not entirely appropriate for a daily newspaper. This could result in a bored readership, a less popular journalist and a research organisation that has, rather than engaging the public on a key policy issue, either failed to get people on board or alienated them. Newspaper readers don't want to read a long, wordy report intended for, and written by policymakers (many policymakers probably don't either). A more successful situation for journalist, policymaker, and reader would be one where the report was paraphrased, condensed, and linked to a real-life example and told like a story in a Pacific way. 'NGOs can also look at how they tailor their messages for traditional media to easily push it out (Narakobi, E., interview with the author, 10 August 2012).'

\section{Conclusion}

The key message here is that while media freedom is indeed important and worth fighting for, there is a lot more to the story. The media in the Pacific appear to be faced with a few main options - ignore media freedom issues; 
write articles overseas about how unfair things are; write the stories they want to at risk of persecution; or attempt to have a positive influence within the imperfect system in which they find themselves - perhaps by exercising a willingness to work outside their traditional print media systems. Different approaches will have their own merits and drawbacks and the outcomes will vary depending on the context within each country.

There is potential to push for a freer media in a way that is harmonious with Pacific cultures and ideals and each country has the opportunity to plot its own course and choose its own way. There are avenues available for traditional media to engage more, not only with the public and social media but also with governments themselves. We should be willing and ready to acknowledge that alternative methods can be employed to push for a common cause - a Pacific region with more accountable, stronger governments that allow more effective and freer communication and therefore, governments willing to evolve and develop their democracies to better serve their peoples.

\section{Note}

1. It is worth noting that this is not always the case, with instances of harassment after people, using their real name, publicly embarrassed police, politicians and other powerful people on social media sites such as Facebook.

\section{References}

Benkler, Y. (2006). The wealth of networks: How social production transforms markets and freedom. New Haven CT: Yale University. Cited in Montgomery, K. C. (2008), Youth and digital democracy: Intersections of practice, policy, and the marketplace. In Bennett, W. L. (Ed.), Civic life online: Learning how digital media can engage youth (pp. 25-50). Cambridge, MA: The John D. and Catherine T. MacArthur Foundation Series on Digital Media and Learning; The MIT Press.

Cave, D. (2012). Digital islands: How the Pacific's ICT revolution is transforming the region. Lowy Institute. Retrieved on April 15, 2013, from www.lowyinstitute. org/publications/digital-islands-how-pacifics-ict-revolution-transforming-region

Foster, S. (2007). Who let the blogs out? Media and free speech in post-coup Fiji. Pacific Journalism Review, 13(2), 47-60.

Hayward-Jones, J. (2011). Lowy Institute Fiji Poll 2011: Fiji at home in the worldpublic opinion and foreign policy. Lowy Institute. Retrieved on January 24, 2013, from http://lowyinstitute.cachefly.net/files/pubfiles/Lowy_Poll_FIJI_WEB.pdf 


\section{MEDIA AND DEMOCRACY IN THE PACIFIC}

Larmour, P. (2012). Interpreting corruption, culture and politics in the Pacific Islands. Honolulu: University of Hawai'i Press.

Loanakadavu, N. (2012). Be heard!, Fiji Times Online. Retrieved on August 9, 2012, from www.fijitimes.com/story.aspx?id=208684

Logan, S. (2012). Rausim! Digital politics in Papua New Guinea. State, Society \& Governance in Melanesia Program 2012/9, Australian National University. Retrieved on April 15, 2013, from (pdf) http://ips.cap.anu.edu.au/ssgm/papers/ discussion_papers/2012_9.pdf

Net Benefits (2012). PiPP discussion paper 20. Retrieved on January 24, 2013, from www.pacificpolicy.org/wp-content/uploads/2012/05/DP20-PiPP.pdf

Rooney, M. (2012). Can social media transform Papua New Guinea? Reflections and questions, Devpolicy Blog. Retrieved on August 1, 2012, from http://devpolicy.org/ can-social-media-transform-papua-new-guinea-reflections-and-questions/

Soroka, S., Lawlor, A., Farnsworth, S., \& Young L. (2013). Mass media and policy making. In Wu Xun, W., Ramesh, M., Howlett, M., Fritzen S., \& Araral, E. (Eds.), Routledge handbook of the policy process, Part IV, Chapter 16 (pp. 204 - 215). New York: Routledge.

Urban Hymns (2011). PiPP discussion paper 18. Retrieved on January 24, 2013, from www.pacificpolicy.org/wp-content/uploads/2012/05/D18-PiPP.pdf

Walsh, C. (2010). Political blogs on Fiji: A ‘cybernet democracy' case study. Pacific Journalism Review, 16(1), 154-177. Retrieved on April 16, 2012, from www. pjreview.info/articles/political-blogs-fiji-cybernet-democracy-case-study-572

\section{Interviews and correspondence}

Cooney, C. (2012, August 18). Correspondence with the author.

Dorney, S. (2012, August 13). Correspondence with the author.

Herman, F. (2012, August 8). Interview with the author.

Moala, K. (2012, July 12). Interview with the author.

Narakobi, E. (2012, August 10). Interview with the author.

Toby Ley is a research associate with the Pacific Institute of Public Policy (PiPP) in Port Vila, Vanuatu. An earlier version of this paper was presented by Toby Ley and Talita Tu'ipulotu, senior communications officer (PiPP), at the Media and Democracy in the South Pacific Symposium, University of the South Pacific, Suva, Fiji, 5-6 September 2012.

tobyley@gmail.com 